\title{
Keratinized Spindle Cell: A Diagnostic Cytological Atypia In Human Oral Carcinoma
}

\author{
*Dr Abhimanyu Mohanta, Ph.D ${ }^{1}$; Dr Prafulla K. Mohanty, Ph.D ${ }^{2}$; \\ Dr Gadadhar Parida, M.D. ${ }^{3}$ \\ ${ }^{1 .}$ UGC Research Fellow, P.G. Department of Zoology, Utkal University, Vani Vihar, Bhubaneshwar, Odisha, \\ India- 751004. \\ 2.Professor and Head, P.G. Department of Zoology, Utkal University, Vani Vihar, Bhubaneshwar, Odisha, \\ India-751004. \\ ${ }^{3}$ Former Professor and Head, Department of Oncopathology, Acharya Harihar Regional Cancer Centre \\ (AHRCC), Cuttack, Odisha, India-753 007.
}

\begin{abstract}
:
Background: Cytological pleomorphism is a unique and well exhibited phenomenon during oral carcinogenesis. Genesis and occurrence of cytological atypias in oral epithelium of carcinoma patients help the Cytopathologists in determining the type of tumor and even in early detection.

Materials and Methods: In a case- control study, samples in the form of exfoliated scraped cytosmear were collected from the affected sites of the clinically diagnosed 136 oral cancer patients and were immediately fixed in acetoalcohol (1:3). The wet fixed smears were stained by routine Papanicolaou's staining protocol and Giemsa's solution. Stained tissues were studied under the microscope. Out of one thousand cells screened,well defined cytological atypias were scored. The nuclear-cytoplasmic ratio $(N / C)$ was calculated after taking the area of the cytoplasm $(C)$ and nucleus $(N)$ of the respective cell. The findings were statistically analyzed and interpreted with respect to oral sites and sexes.

Results and Discussion: The keratinized spindle cell is the predominant atypia in the human oral spindle cell carcinoma ( $\mathrm{SpCC}$ ), which shows both cytological and nuclear pleomorphism and identifiable mitoses. Increased nuclear-cytoplasmic ratio in KSCs was found to be 1:11.6 in males and 1:9.5 in females indicates the state of malignancy.

Conclusion: Occurrence of KSCS in oral epithelia has a practical utility in early detection and diagnosis of human oral carcinoma during carcinogenesis.
\end{abstract}

Key words: Cytological atypia, Keratinized spindle cell, Spindle cell carcinoma, malignancy, Nuclearcytoplasmic (N/C) ratio.

\section{Introduction}

Exfoliated scrape cytology reveals that cellular pleomorphism is a common feature in human oral squamous cell carcinoma (OSCC). Out of a number of diagnostic pleomorphic cells, keratinized spindle cell (KSC) is found to be unique and important cytological atypia so far as cytopathology is concerned. On the basis of occurrence of KSCs, the World Health Organization (WHO) classification of tumors of the oral cavity and oropharynx has placed this disease entity under malignant epithelial tumors of squamous cell carcinoma (SCC) and labelled it "Spindle cell carcinoma" (SpCC) [1]. Although the histological features of SpCC have been well described, its cytological features have not been adequately reported. Some authors have also confusingly reported the spindle cell component as non-neoplastic reactive connective tissue responses to overlying SCC [2,3]. Again, it was suggested that the spindle cell component represented a transformation of a SCC that had been subjected to radiotherapy or solar damage or trauma [4].

Oral cavity is readily accessible for inspection and examination, even by the patient. But, it is unfortunate that patients still present with advanced tumors. OSCC, at an early stage, is generally asymptomatic and probably due to this, diagnosis and treatment are all too often delayed until the cancer is malignant or has spread to cervical lymph nodes [5,6]. Similarly, the cytopathologists very often encounter problems in detection and diagnoses of the OSCC patients as most of the oral squamous cells appear to be either well differentiated or moderately differentiated and mimic to be benign and non-neoplastic. Contrary to that, many benign and nonneoplastic lesions appear to be malignant neoplasm [7-9]. Therefore, in the present investigation, an attempt has been undertaken to analyze the importance of rare occurrence of keratinized spindle cells (KSCs) in the buccal mucosa of human OSCC cases. 


\section{Materials and Methods}

\subsection{Collection of samples}

A case-control study was undertaken for which the exfoliated cytosmears were collected by scraping from the clinically diagnosed 136 patients suffering from precancerous lesions and oral squamous cell carcinoma (OSCC) at the Out-patient Department (OPD) of Acharya Harihar Regional Cancer Centre (AHRCC), Cuttack, Odisha, during May 2007-May 2009. Smearing was done on the pre-cleaned-coded microslides and immediately, the slides were fixed in acetoalcohol (1:3) fixative. Two slides were smeared and prepared from each affected site of the patient. Prior to the collection of samples, case-history of the patients related to their age, sex, food, habits (addiction to tobacco, alcohol etc.), oral hygiene and occupation were asked and recorded for detail analysis. A parallel set of 136 samples were also collected from the non-addicted and non-cancerous healthy individuals from different regions of Odisha which is considered as control group.

\subsection{Staining protocol and scoring}

Wet fixed cytosmears were stained by adopting Papanicolaou's staining protocol and counter stained with Giemsa's solution. Out of one thousand screened cells, pleomorphic keratinized spindle cells (KSCs) were scored with utmost care.

\subsection{Statistical analyses}

The mean length and breadth of the squamous cell was taken into account as length and breadth of the $\mathrm{KSC}$, as each cell was measured at three regions (middle and on its either sides) - in length and breadth-wise by using computer-assisted Cat Cam: Microscope camera of Catalyst Biotech. The measured values were tabulated. The nuclear-cytoplasmic ratio (N/C) was calculated after taking the area of the cytoplasm $(\mathrm{C})$ and nucleus $(\mathrm{N})$ of the respective cell. The findings were statistically analyzed and interpreted with respect to oral sites and sexes.

\subsection{Ethical considerations}

This study was approved by Subject Research Committee (SRC) of Utkal University, Bhubaneshwar, Odisha, India and necessary permission was also obtained from the Director, AHRCC, Cuttack, Odisha, India.

\section{Results}

Structurally, when the cells appear to be spindle shaped and the cytoplasms get keratinized, those particular cells are named as keratinized spindle cells (KSCs). The KSCs were moderately differentiated and were mostly observed in both in premalignant and malignant cases. The cytoplasms were basophilic with almost ill-defined cell membrane. On the other hand, the smear taken from the base of the tumor showed sheets and clumping of atypical squamous cells, both hypo- and hyperkeratinized, and hyperchromatic nuclei with increased N/C ratio. Rarely, KSCs were found to be micronucleated (Fig.1). In some cases, cytoplasmic bridge and nuclear pleomorphism were visualized during the genesis of KSCs (Fig.2). Ctyological pleomorphism in KSCs was a common feature of occurrence (Fig.3). The KSCs were observed in 26 (31.7 per cent) male samples and in 20 (37.03 per cent) cases of females. Thus, the male to female ratio in our study is 1.3:1. It is important to note that not a single KSC was observed in the samples of control group.

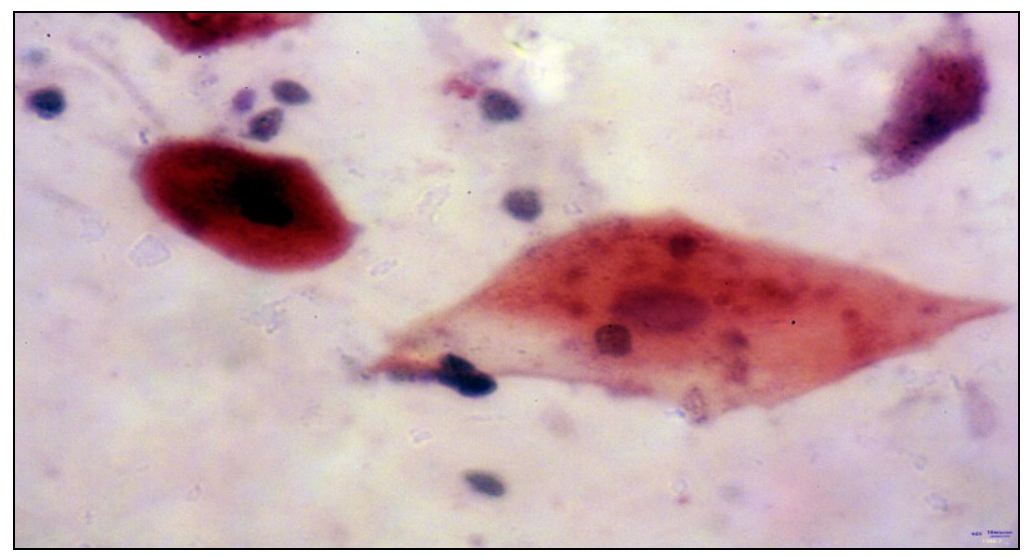

Fig.1 Rarely observed a keratinized spindle cells with an ill-defined cell membrane and three prominent micronuclei (Papanicolaous' stain x 400). 


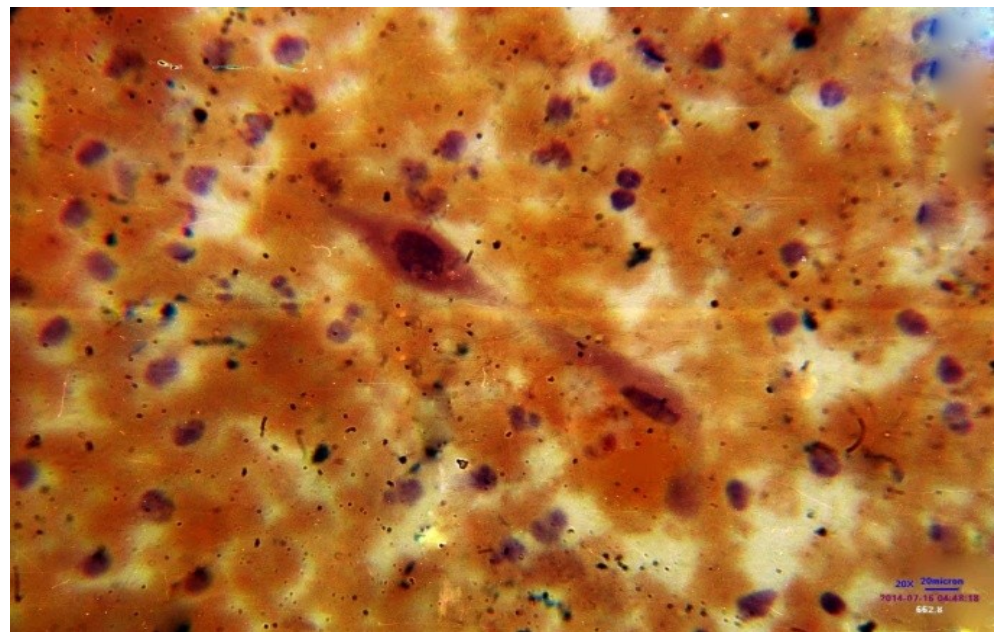

Fig.2 Keratinized spindle cells with cytoplasmic bridge, exhibiting amitosis and nuclear pleomorphism (Papanicolaous' stain x 200).

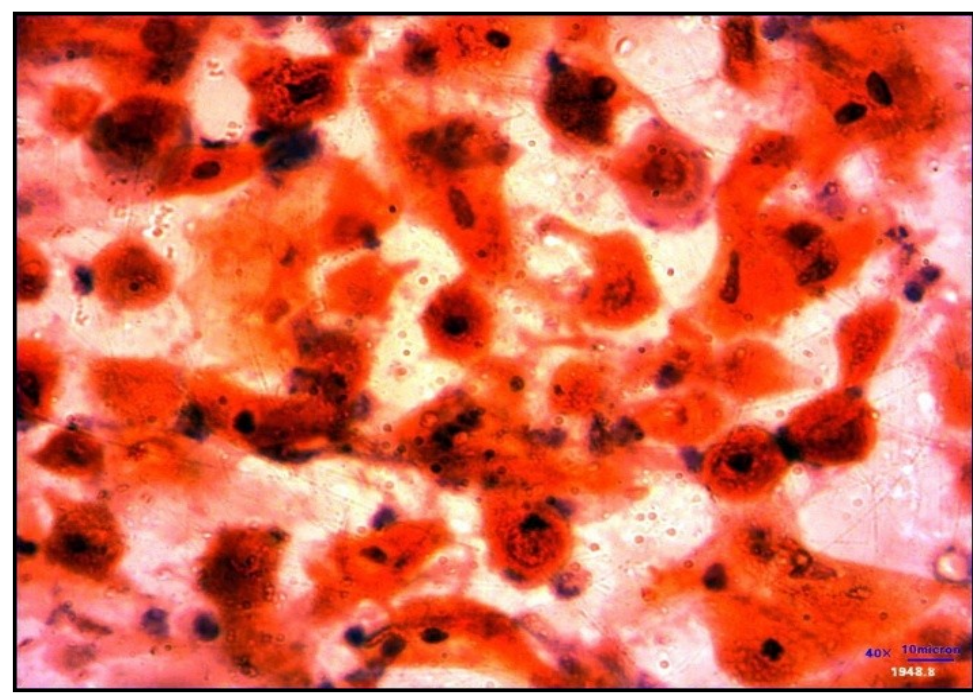

Fig.3 Pleomorphic keratinized spindle cells (Papanicolaous’ stain x 400).

The total number of KSCs scored from 82 males was 695 (0.847 per cent) and 835 (1.546 per cent) from 54 females (Table 1). Irrespective of the age groups, the highest number of samples with KSCs was recorded from the buccal mucosa of 3 males and 4 females in 50-69 years and the lowest in palate (Fig.4). Also, the highest number of KSCs were scored from the buccal mucosa (52.81 per cent in male and 54.37 per cent in female) and it was the lowest in palate (4.89 per cent in male and 3.35 in female) (Fig.5). So far as mean frequency of the KSCs is concerned, the highest score was obtained from tongue (1.145 per cent in male and 1.92 per cent in female) and the lowest from alveolus and gingiva ( 0.275 per cent in males) and palate ( 0.93 per cent in females) respectively.

The spindle shaped cell is the predominant atypia in the human oral neoplasm, which shows nuclear pleomorphism and identifiable mitoses. Irrespective of shape and size of the KSCs, four types of nuclear pleomorphism (namely round, oval, spindle and bar-shaped) were detected from the premalignant and malignant cases. The frequencies of round, oval and bar shaped nuclei in KSCs were calculated to be the highest in premalignant females; whereas spindle shaped nuclei were found to be the highest in malignant males (Fig.6). 
Table 1 Oral sites, age groups and sex-wise enumeration of the KSCs

\begin{tabular}{|c|c|c|c|c|c|c|c|c|c|c|c|c|}
\hline \multirow{2}{*}{$\begin{array}{l}\mathrm{N} \\
\mathbf{0}\end{array}$} & \multirow{2}{*}{$\begin{array}{c}\text { Sites } \\
(\text { ICD-10) }\end{array}$} & \multirow{2}{*}{$\begin{array}{c}\text { Age } \\
\text { groups } \\
\text { in years }\end{array}$} & \multicolumn{2}{|c|}{ No. of samples } & \multicolumn{2}{|c|}{$\begin{array}{c}\text { No. of samples with } \\
\text { KSCs } \\
\end{array}$} & \multicolumn{2}{|c|}{ KSCs scored } & \multicolumn{2}{|c|}{$\begin{array}{c}\text { Total number of KSC } \\
\text { scored }\end{array}$} & \multicolumn{2}{|c|}{$\begin{array}{c}\text { Mean Frequency } \\
(\%)\end{array}$} \\
\hline & & & Male & Female & Male & Female & Male & Female & Male & Female & Male & Female \\
\hline \multirow{3}{*}{1} & \multirow{3}{*}{ Lip } & $30-49$ & 02 & Nil & 01 & Nil & 18 & Nil & \multirow{3}{*}{$\begin{array}{l}56 \\
(8.06)\end{array}$} & \multirow{3}{*}{$\begin{array}{l}63 \\
(7.55)\end{array}$} & \multirow{3}{*}{1.12} & \multirow{3}{*}{1.05} \\
\hline & & $50-69$ & 02 & 04 & 01 & 01 & 22 & 32 & & & & \\
\hline & & $70-89$ & 01 & 02 & 01 & 01 & 16 & 31 & & & & \\
\hline \multirow{3}{*}{2} & \multirow{3}{*}{$\begin{array}{l}\text { Tongu } \\
\mathrm{e}\end{array}$} & $30-49$ & 05 & 02 & 02 & 01 & 34 & 28 & \multirow{3}{*}{$\begin{array}{l}126 \\
(18.13 \\
)\end{array}$} & \multirow{3}{*}{$\begin{array}{l}135 \\
(16.17 \\
) \\
\end{array}$} & \multirow{3}{*}{$\begin{array}{l}1.14 \\
5\end{array}$} & \multirow{3}{*}{1.92} \\
\hline & & $50-69$ & 05 & 04 & 02 & 02 & 57 & 72 & & & & \\
\hline & & $70-89$ & 01 & 01 & 01 & 01 & 35 & 35 & & & & \\
\hline \multirow{3}{*}{3} & \multirow{3}{*}{$\begin{array}{l}\text { Alveol } \\
\text { us and } \\
\text { gingiv } \\
\text { a }\end{array}$} & $30-49$ & 04 & 03 & 01 & 02 & 08 & 38 & \multirow{3}{*}{$\begin{array}{l}44 \\
(6.33)\end{array}$} & \multirow{3}{*}{$\begin{array}{l}78 \\
(9.34)\end{array}$} & \multirow{3}{*}{$\begin{array}{l}0.27 \\
5\end{array}$} & \multirow{3}{*}{1.3} \\
\hline & & $50-69$ & 08 & 03 & 02 & 01 & 24 & 40 & & & & \\
\hline & & $70-89$ & 04 & Nil & 01 & Nil & 12 & Nil & & & & \\
\hline \multirow{3}{*}{4} & \multirow{3}{*}{$\begin{array}{l}\text { Floor } \\
\text { of the } \\
\text { mouth }\end{array}$} & $30-49$ & 04 & 01 & 02 & 01 & 35 & 12 & \multirow{3}{*}{$\begin{array}{l}68 \\
(9.78)\end{array}$} & \multirow{3}{*}{$\begin{array}{l}77 \\
(9.22)\end{array}$} & \multirow{3}{*}{$\begin{array}{l}0.97 \\
1\end{array}$} & \multirow{3}{*}{1.1} \\
\hline & & $50-69$ & 02 & 04 & 01 & 01 & 20 & 57 & & & & \\
\hline & & $70-89$ & 01 & 01 & 01 & 01 & 13 & 08 & & & & \\
\hline & & $30-49$ & 04 & 01 & 01 & 01 & 16 & 09 & & & & \\
\hline 5 & Palate & $50-69$ & 01 & 02 & 01 & 01 & 08 & 19 & 34 & 28 & 0.56 & 0.93 \\
\hline & & $70-89$ & 01 & Nil & 01 & Nil & 10 & Nil & & & & \\
\hline & Buccal & $30-49$ & 14 & 04 & 02 & 01 & 105 & 78 & & & & \\
\hline 6 & mucos & $50-69$ & 16 & 19 & 03 & 04 & 164 & 246 & (52.81 & $(54.37$ & 0.99 & 1.746 \\
\hline & $\mathrm{a}$ & $70-89$ & 07 & 03 & 02 & 01 & 98 & 130 & ) & ) & & \\
\hline To & & $30-89$ & 82 & 54 & 26 & 20 & 695 & 835 & $\begin{array}{l}695 \\
(100)\end{array}$ & $\begin{array}{l}835 \\
(100)\end{array}$ & $\begin{array}{l}0.84 \\
7\end{array}$ & 1.546 \\
\hline
\end{tabular}

N.B.-Figures in parentheses indicate the relative percentage of KSCs with respect to all sites.

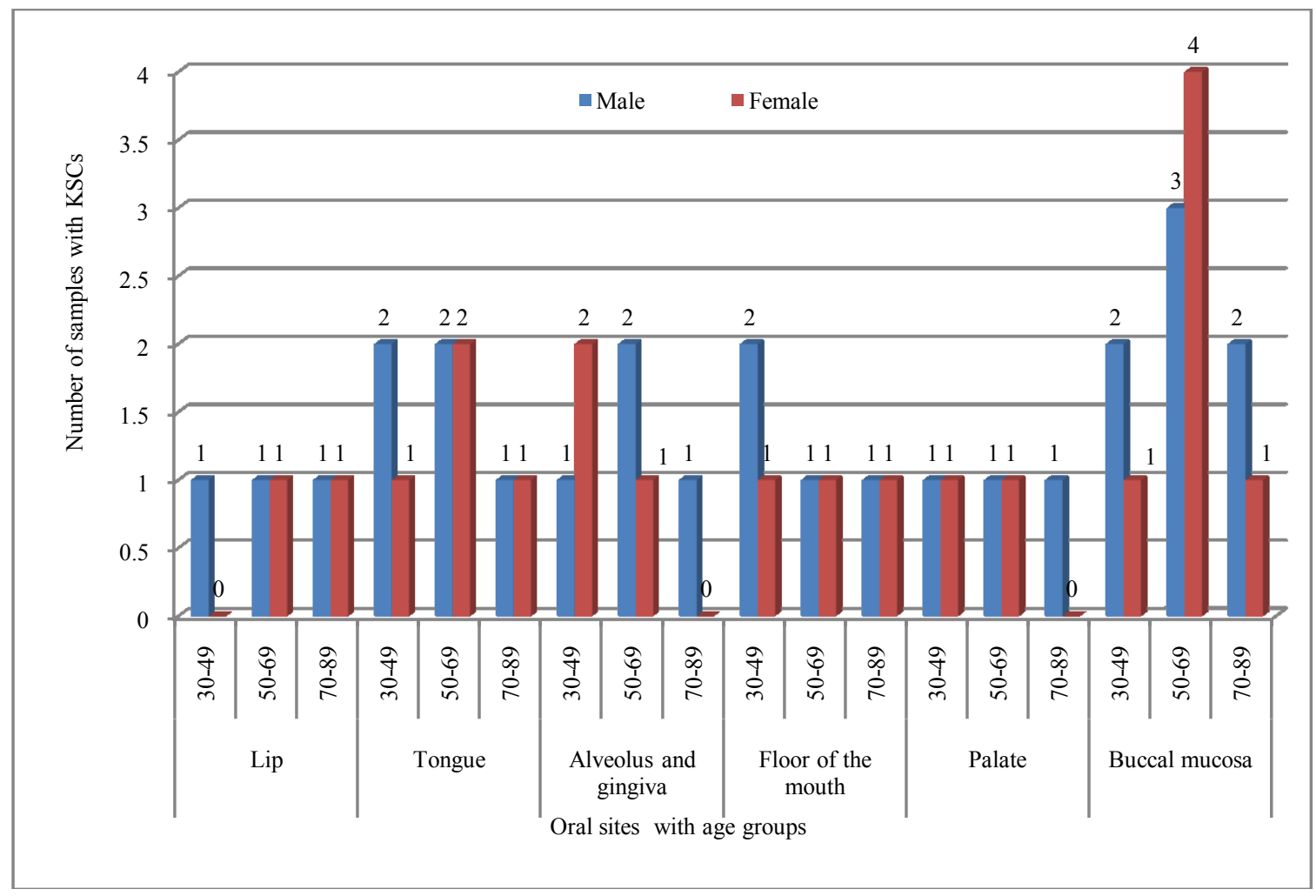

Fig.4 Oral site, age groups and sex-wise number of samples with KSCs. 


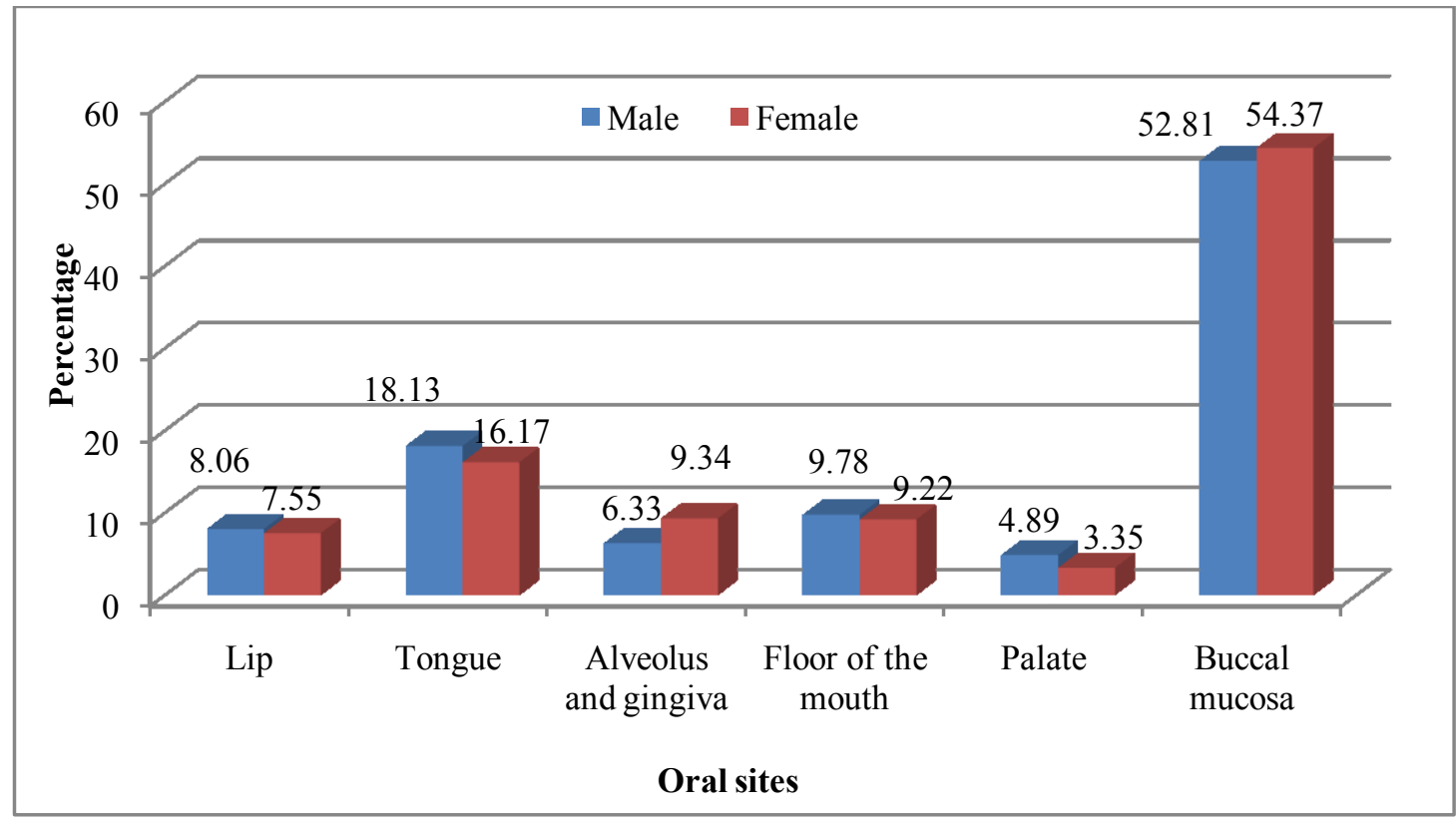

Fig.5 Oral site and sex-wise relative percentage of KSCs.

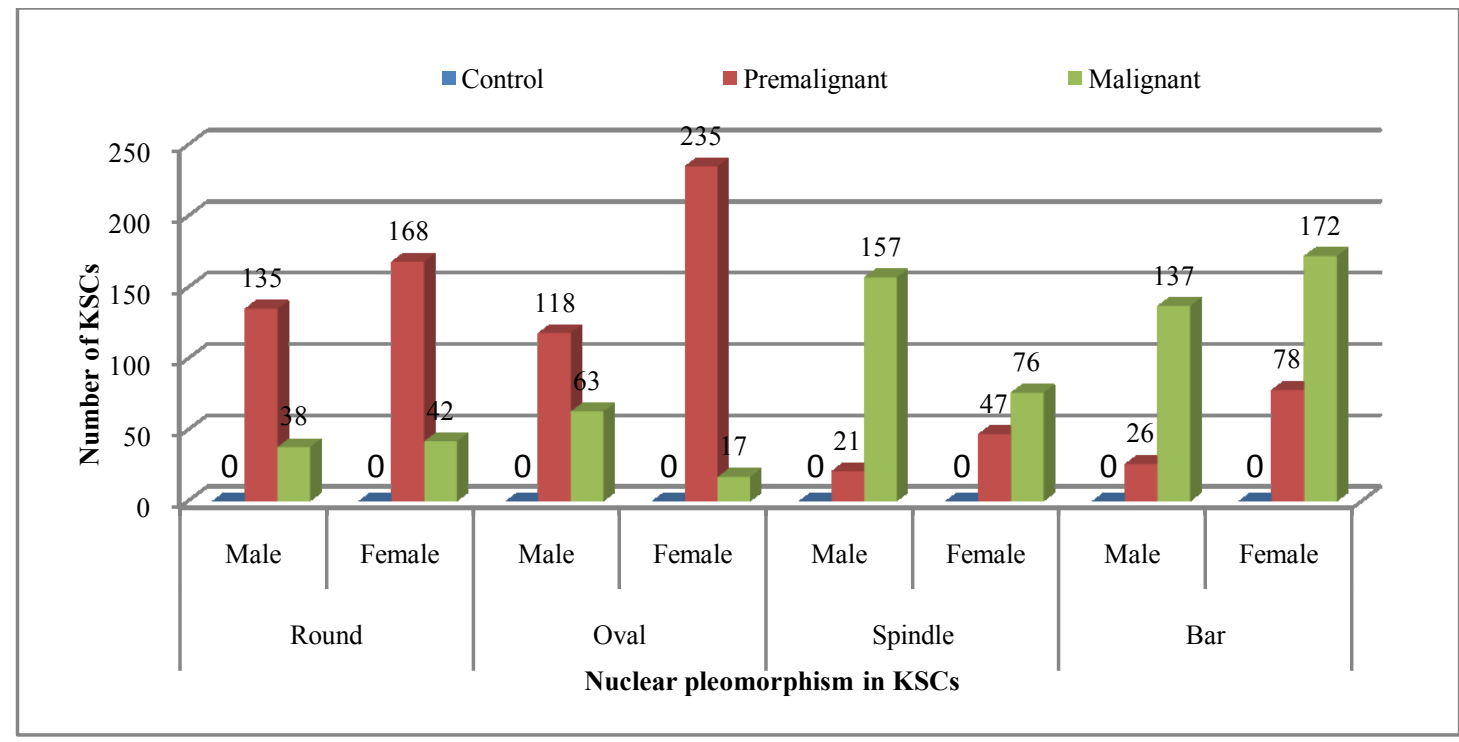

Fig. 6 Sex-wise enumeration of nuclear pleomorphism in KSCs.

Cytometric analysis (Table 2) showed that the mean length and breadth of the normal oral squamous cells (NOSCs) in males were $86.50 \mu \mathrm{m}( \pm 17.234 \mu \mathrm{m})$ and $64.23 \mu \mathrm{m}( \pm 12.125 \mu \mathrm{m})$ respectively having an area of $5555.89 \mu \mathrm{m}^{2}\left( \pm 208.362 \mu \mathrm{m}^{2}\right)$. The nucleus of the normal squamous cell in male was measured to be $12.95 \mu \mathrm{m}( \pm 3.368 \mu \mathrm{m})$ in length and $12.43 \mu \mathrm{m}( \pm 3.235 \mu \mathrm{m})$ in breadth with an area of $160.968 \mu \mathrm{m}^{2}\left(+10.895 \mu \mathrm{m}^{2}\right)$. The nuclear-cytoplasmic ratio $(\mathrm{N} / \mathrm{C})$ in males was calculated to be $1: 34.5$. In females, the mean length, breadth and area of the normal oral squamous cells were $85.875 \mu \mathrm{m}$ $( \pm 16.374 \mu \mathrm{m}), 65.012 \mu \mathrm{m}( \pm 11.876 \mu \mathrm{m})$ and $5582.905 \mu \mathrm{m}^{2}\left( \pm 194.457 \mu \mathrm{m}^{2}\right)$ respectively. The mean length and breadth of the nucleus were $12.920 \mu \mathrm{m}( \pm 3.544 \mu \mathrm{m})$ and $12.530 \mu \mathrm{m}( \pm 3.452 \mu \mathrm{m})$. Thus, the mean nuclear area of the normal squamous cells in females was found to be $161.887 \mu \mathrm{m}^{2}\left( \pm 12.233 \mu \mathrm{m}^{2}\right)$. Hence, the nuclear-cytoplasmic $(\mathrm{N} / \mathrm{C})$ ratio in females was found to be 1:34.4. Variations occur in staining of the exfoliated mature normal cells. But mostly, the cells are basophilic and appeared to be sky blue in colour in Papanicolaou's staining.

The size of the keratinized spindle cells (KSCs) varies in both the sexes. The mean length of the spindle cell was $54.649 \mu \mathrm{m}( \pm 6.341 \mu \mathrm{m})$ and the breadth was $16.835 \mu \mathrm{m}( \pm 7.725 \mu \mathrm{m})$ in male. Its mean area was calculated to be $920.01 \mu \mathrm{m}^{2}\left( \pm 48.984 \mu \mathrm{m}^{2}\right)$. The nuclear length and breadth of the KSC were $9.842 \mu \mathrm{m}$ 
$( \pm 2.140 \mu \mathrm{m})$ and $8.029 \mu \mathrm{m}( \pm 1.810 \mu \mathrm{m})$. The nuclear area was measured to be $79.02 \mu \mathrm{m}^{2}\left( \pm 3.873 \mu \mathrm{m}^{2}\right)$. Hence, the nuclear-cytoplasmic ratio in males was 1:11.6. In case of female, the mean length of the keratinized spindle cell (KSC) was $52.561 \mu \mathrm{m}( \pm 7.082)$ and its breadth was $14.165 \mu \mathrm{m}( \pm 6.702 \mu \mathrm{m})$. Its area was found to be $776.063 \mu \mathrm{m}^{2}\left( \pm 47.463 \mu \mathrm{m}^{2}\right)$. The mean length and breadth of the nucleus of the KSCs were $9.325 \mu \mathrm{m}( \pm 2.781 \mu \mathrm{m})$ and $8.726 \mu \mathrm{m}( \pm 1.803 \mu \mathrm{m})$. Its nuclear area was $81.369 \mu \mathrm{m}^{2}\left( \pm 5.014 \mu \mathrm{m}^{2}\right)$ and thus, the N/C ratio was found to be 1:9.5 (Fig.7).

Table 2 A comparative accounts of N/C ratios between Normal oral squamous cell and Keratinized spindle cell in either sex

\begin{tabular}{|c|c|c|c|c|c|c|c|c|c|c|}
\hline \multirow[b]{2}{*}{ No } & \multirow[b]{2}{*}{ Cell type } & \multirow[b]{2}{*}{ Sex } & \multirow{2}{*}{$\begin{array}{l}\text { Total } \\
\text { no of } \\
\text { KSCs } \\
\text { scored }\end{array}$} & \multicolumn{3}{|c|}{ Cytoplasm ( C ) } & \multicolumn{3}{|c|}{ Nucleus (N) } & \multirow[b]{2}{*}{$\begin{array}{l}\mathrm{N} / \mathrm{C} \\
\text { Ratio }\end{array}$} \\
\hline & & & & $\begin{array}{l}\text { Mean } \\
\text { length } \\
\text { in } \\
\mu \mathrm{m}+\mathrm{SD}\end{array}$ & $\begin{array}{l}\text { Mean } \\
\text { breadth } \\
\text { in } \\
\mu \mathrm{m}+\mathrm{SD}\end{array}$ & $\begin{array}{l}\text { Mean area } \\
\text { in } \mu \mathrm{m}^{2} \pm \\
\mathrm{SD}\end{array}$ & $\begin{array}{l}\text { Mean } \\
\text { length } \\
\text { in } \\
\mu \mathrm{m}+\mathrm{SD}\end{array}$ & $\begin{array}{l}\text { Mean } \\
\text { breadth } \\
\text { in } \\
\mu \mathrm{m}+\mathrm{SD}\end{array}$ & $\begin{array}{l}\text { Mean } \\
\text { area } \\
\mu \mathrm{m}^{2} \\
\mathrm{SD}\end{array}$ & \\
\hline \multirow{2}{*}{1} & \multirow{2}{*}{$\begin{array}{l}\text { Normal } \\
\text { cell }\end{array}$} & Male & 1000 & $\begin{array}{l}86.50 \\
\pm 2.234\end{array}$ & $\begin{array}{l}64.23 \\
\pm 2.125\end{array}$ & $\begin{array}{l}5555.89 \\
\pm 4.747\end{array}$ & $\begin{array}{l}12.95 \\
\pm 1.368\end{array}$ & $\begin{array}{l}12.43 \\
\pm 1.235\end{array}$ & $\begin{array}{l}160.968 \\
\pm 1.689\end{array}$ & $1: 34.5$ \\
\hline & & Female & 1000 & $\begin{array}{l}85.875 \\
\pm 2.370\end{array}$ & $\begin{array}{l}65.012 \\
\pm 1.876\end{array}$ & $\begin{array}{l}5582.905 \\
\pm 4.446\end{array}$ & $\begin{array}{l}12.920 \\
\pm 1.540\end{array}$ & $\begin{array}{l}12.530 \\
\pm 1.450\end{array}$ & $\begin{array}{l}161.887 \\
\pm 2.233\end{array}$ & $1: 34.4$ \\
\hline \multirow{2}{*}{2} & \multirow{2}{*}{$\mathrm{KSC}$} & Male & 695 & $\begin{array}{l}54.649 \\
\pm 6.341\end{array}$ & $\begin{array}{l}16.835 \\
\pm 7.725\end{array}$ & $\begin{array}{l}920.01 \\
\pm 48.984\end{array}$ & $\begin{array}{l}9.842 \\
\pm 2.140\end{array}$ & $\begin{array}{l}8.029 \\
\pm 1.810\end{array}$ & $\begin{array}{l}79.02 \\
\pm 3.873\end{array}$ & 1:11.6 \\
\hline & & Female & 835 & $\begin{array}{l}52.561 \\
\pm 7.082\end{array}$ & $\begin{array}{l}14.765 \\
\pm 6.702\end{array}$ & $\begin{array}{l}776.063 \\
\pm 47.463\end{array}$ & $\begin{array}{l}9.352 \\
\pm 1.781\end{array}$ & $\begin{array}{l}8.726 \\
\pm 1.803\end{array}$ & $\begin{array}{l}81.369 \\
\pm 5.014\end{array}$ & $1: 9.5$ \\
\hline
\end{tabular}

N.B.- SD stands for Standard deviation.

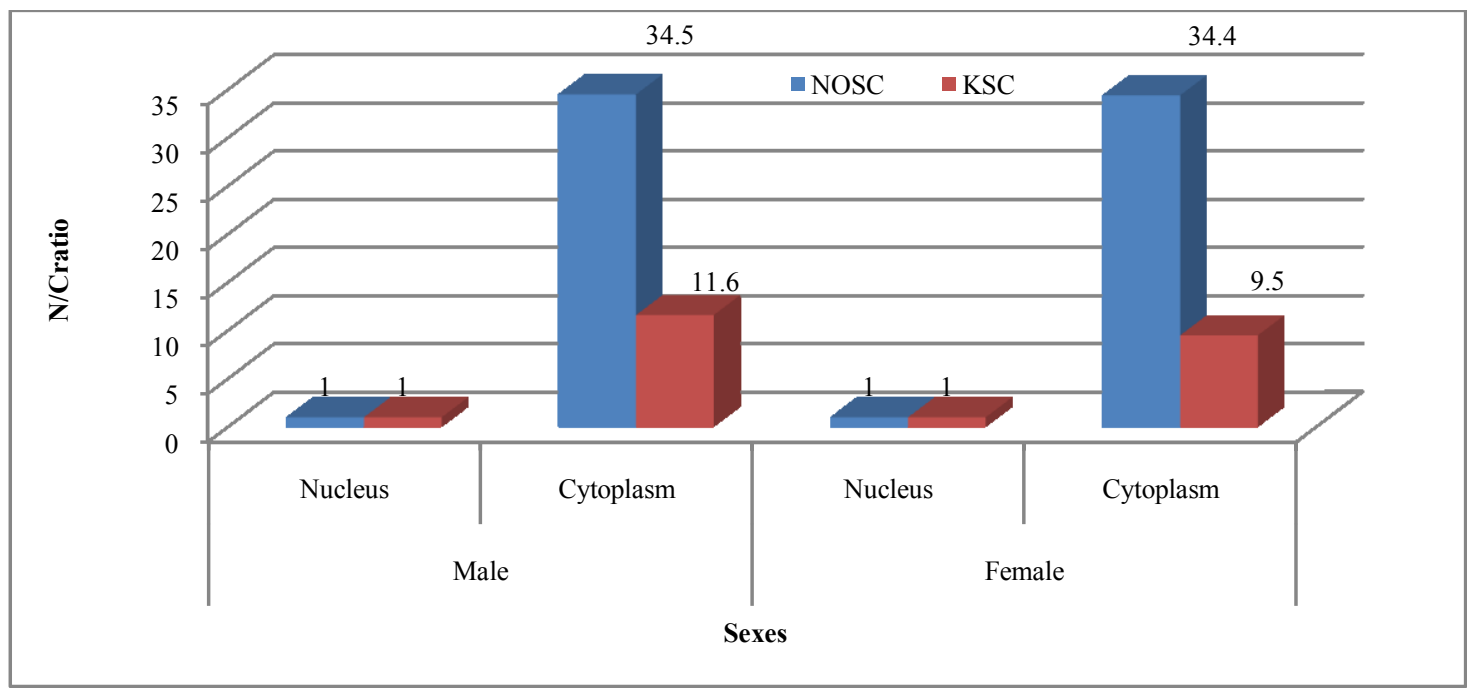

Fig. 7 N/C ratios in NOSCs and KSCs in both sexes.

\section{Discussion}

Spindle cell neoplasms comprise a diverse collection of benign and malignant tumors. These tumors are uncommon in the oral cavity; reportedly accounting for less than $1 \%$ of all tumors of oral regions [10]. Spindle cell carcinoma ( $\mathrm{SpCC}$ ) is a rare and peculiar biphasic malignant neoplasm of head and neck. It consists of sarcomatoid proliferation of pleomorphic spindle-shaped cells and squamous cell carcinoma [11]. Some of the earlier workers have reported that $\mathrm{SpCC}$ is an unusual form of poorly differentiated squamous cell 
carcinoma (SCC) consisting of elongated (spindle) epithelial cells that resemble a sarcoma. Many of these tumors may be easily confused with true sarcomas unless special immunohistologic or ultrastructural analysis is performed. Such analyses show concurrent presence of malignant epithelial and homologous sarcomatoid spindle cell components by co-expression of cytokeratin, epithelial membrane antigen, and vimentin to various degrees [12]. When spindle shaped and atypical squamous cells are found by smearing, in addition to clinical features, the diagnosis of a polypoid oral cancer should be considered [13].

In our study, the keratinized spindle cells (KSCs) are found to be moderately differentiated, pleomorphic and resemble a sarcoma and also mimic to be benign and non-neoplastic. As a result the cytopathologists very often encounter problems in detection and diagnoses of the OSCC patients. No doubt, the KSCs were observed both in the benign and malignant cases, hyperkeratinization and increased N/C ratios in KSCs not only indicate epithelial origin but also malignancy.

Zarbo et al. have suggested that the spindle cell components have been considered to be either a variant growth pattern of SCC, a non-neoplastic mesenchymal reaction, or a malignant admixture of epithelial and mesenchymal neoplasms [14]. However, Lewis et al. reported that the majority of the spindle cell components are non-diploid, which indicates that they are neoplastic and not reactive [15]. The vimentin positivity also reflects that these bizarre fibroblast-like cells are carcinoma cells with true mesenchymal metaplasia [16]. When the spindle cell component was compared with its corresponding epithelial component, identical patterns of p53 protein expression were noted in $95 \%$ of the biphasic tumors [17]. Recently, p63 has been reported as a useful marker for spindle cell carcinoma [18]. These comprise evidence that the malignant spindle cells are due to metaplasia from the involved epithelium, and are neither inflammatory reaction nor true sarcoma.

The spindle shape of the tumor cells has been considered to be caused by the lack of expression of cell adhesion molecule such as cadherins and the consequent alteration of keratin filament network [19]. Battifora reported the actual transformation of epithelial cells into mesenchymal cells. The presence of junctional complexes between tumor cells, with or without pericellular basal lamina and cytoplasmic skeins of intermediate filament has been demonstrated [20]. It has been suggested that development of the spindle cell phenotype involves functional loss of genes that control epithelial differentiation and that conversion to spindle morphology is a recessive entry [21]. It has been documented that keratin proteins may be regarded as molecular markers for stratified squamous epithelial cells in normal tissues and in neoplasms. However, Ellis et al. demonstrated that $40 \%$ of spindle cell carcinomas would have a negative keratin stain [22]. Possible reasons for the inability to detect keratin are decreased numbers of cells producing keratin, decreased amount of keratin within these cells, and decreased immune-reactivity of the keratin due to formalin fixation. Thus, a positive keratin stain confirms the diagnosis of squamous cell carcinoma, but a negative result does not rule it out $[23,24]$. Takata et al. have also opined that SpCC should not be ruled out of the differential diagnosis by a positive reaction for vimentin in sarcomatoid tumour cells in the immunohistochemical differential diagnosis. Absence of staining for keratin in the sarcomatoid tumour cells does not always exclude SpCC, because some $\mathrm{SpCCs}$ show immunoreactivity of keratin in their sarcomatoid components only with some anti-keratin antibodies. Therefore, different kinds of anti-keratin antibodies should be applied in the differential diagnosis of SCSC [25].

Spindle cell variant is very rare in childhood and adolescence. A case of spindle cell carcinoma of the tongue in a 4 year old boy has been reported by Kessler and et al [26]. The tumor is usually seen in men with a male to female ratio of 2-4:1 [27]. The male to female ratio in our study is $1.3: 1$. Potential risk factors include a history of tobacco use, poor oral hygiene, alcohol abuse and previous ionizing irradiation of the area [26]. Earlier we have reported that out of 136 oral cancer patients, $126(92.6 \%)$ were addicted to different forms of tobacco and alcohol for more than 15 years, while 10(7.4\%) were non-addicted completely. The addicted individuals were categorized into five different groups, such as chewers, smokers, alcoholics, chewer-smokers and chewer-smoker-alcoholics. All the patients were used to brush their teeth at least once in a day, but in different ways. The findings indicate that the combined effect of tobacco and alcohol has shown more genotoxicity than the single use on the buccal mucosal cells. The formation of more number of micronucleated cells in chewer-smoker-alcoholics group followed by in chewer-smokers than other addicted (chewers, smokers and alcoholics) groups has proved the genotoxic effect of tobacco and alcohol on oral mucosal cells. The results also support the facts of earlier findings that longer the addiction, more the number of micronuclei formation in oral mucosal cells [28]. In this study, rare occurrence of micronuclei in the KSCs clearly indicates that timedose effect of tobacco and alcohol has a positive impact on oral mucosa and genesis of SpCC.

Pattern of kratinization and expression of keratin in the pleomorphic cells in non-keratinized squamous epithelia of the oral cavity is a remarkable feature during carcinogenesis. The atypical pleomorphic cells are observed to be thicker, denser and hyperkeratinized in patients habituated with any form of tobacco and alcohol than the non-addicted cancerous patients. Similarly, the exfoliated mucosal cells collected from occasionally habituated normal individuals are observed to be keratinized so far as non-habituated normal individuals are concerned in our study. The degree of keratinization is also observed to be varying from cell to cell in different 
sites of the same individual is probably due to the habit of keeping tobacco (khaini, gutkha, snuffs etc.), chewing of paan (betel) and paan masala at specific site of the oral cavity. Not only that smoking of tobacco (in the form of bidi and cigarette) and drinking of alcohol may induce the process of keratinization in different sites of the oral cavity demands further study [29].

The spindle cell component is carcinomatous in nature and can occur through the metaplasia of neoplastic squamous cells [30]. In our study, cervical lymph node metastasis was observed in all addicted cancer patients. Su et al. have reported that $\mathrm{SpCC}$ in the oral cavity and oropharynx is potentially aggressive and seems to recur easily and to metastasize. Although, it is difficult to predict biologic behaviour in every case, patients whose tumors are deeply invasive tend to have a poor prognosis, whereas those with early-stage tumors usually have an excellent prognosis [31]. Distant metastases and depth of tumor invasion into underlying structures were found to be reliable prognostic features, together with their polypoid configuration [32]. Thus, metastases usually contain SCC or both SCC and spindle cell component, and rarely only just the spindle cell component [33].

\section{Conclusion}

The keratinized spindle cells (KSCs) occur in various anatomical sites of the oral cavity and exhibit a wide range of microscopic appearances, but some cytological features are quite characteristic and are found in many cases. Pleomorphic spindle shaped body, keratinized cytoplasm and increased N/C ratio have turned the $\mathrm{KSC}$ to be a diagnostic cytological atypia during oral carcinogenesis. In a nut-shell, KSCs, although appear to be moderately differentiated and a predominant component of benign neoplasm, but are really a sign and index of poorly differentiated Spindle cell carcinoma. Thus, occurrence of KSCs in oral mucosa may help the Cytopathologists in early detection of SpCC, particularly, at benign stage. However, the causative factors associated with the genesis of KSCs in oral neoplasm needs further study.

\section{Acknowledgements}

Authors are thankful to the Head, P.G. Dept. of Zoology, Utkal University, Vani Vihar, Bhubaneshwar, Odisha for providing laboratory and library facilities; to the Director, Acharya Haihar Regional Cancer Centre (AHRCC), Cuttack, Odisha for permitting us to collect samples from the oral cancer patients and also for providing library and laboratory facilities and one of us (AM) is grateful to the University Grants Commission (UGC), New Delhi for awarding UGC Meritorious Research Fellowship to carry out the research work.

\section{References}

[1] A. Cardesa, N. Zidar, World Health Organization Classification of Tumours. Head and Neck Tumours: Oral Cavity and Oropharynx, IARC Press, Lyon, 2005, 127-128.

[2] H. Battifora, Spindle cell carcinoma: ultrastructural evidence of squamous origin and collagen production by the tumor cells, Cancer 37, 1976, 275-282.

[3] P.L. Lambert, P.H. Ward, G. Berci, Pseudosarcoma of the larynx: a comprehensive analysis. Arch Otopharyngol., 106, 1980, 700708.

[4] G.W. Greene, J.L. Bernier, Spindle cell carcinoma of the lip: report of four cases. Oral Surg Oral Med Oral Pathol., 12, 1959, 1008-16.

[5] E.W. Strong, R.H. Spiro, Cancer of the oral cavity. In EN Myers and JY Suen (Eds) Cancer of the Head and Neck. Second Edition, (Churchill Livingstone, New York, 1989).

[6] J. Yokota, Tumor progression and metastasis. Carcinogenesis, 21 (3), 2000, 497-503.

[7] F.U. Garcia, General Cytologic Pitfalls. In B.F. Atkinson and J.F. Silverman (Ed) Atlas of Difficult Diagnoses in Cytopathology, (WB Saunders Company, Philadelphia, 1998).

[8] G. Parida, Diagnostic cells in scrape cytology of squamous cell carcinoma. Acta Cytol, 45, 2001, 1085-1086.

[9] E.T. McKinley, General cytologic principles. In Atkinsons BF(Ed). Atlas of Diagnostic Cytopathology, Second Edition (Saunder, Elsevier Inc., Philadelphia, 2004).

[10] R.C.K. Jordan, J.A. Regezi, Oral spindle cell neoplasm: A review of 307 cases, Oral Surg Oral Med Oral Pathol Oral Radiol Endod, 95, 2003, 717-724.

[11] Y.Kudo, I. Ogawa, M. Kitagawa, S.Kitajima, B.S.M.Samadarani Siriwardena, N. Aobara, C.Matsuda, M. Miyauchi , T. Takata, Establishment and characterization of a spindle cell squamous carcinoma cell line. J Oral Pathol Med, 35, 2006, 479-483.

[12] J.G. Batsakis, P. Suarez, Sarcomatoid carcinomas of the upper aerodigestive tracts, Adv Anat Pathol, 7, 2000, 282-293.

[13] S.F. Fifita, K. Kuyama, A. Suzuki, Y. Tamaki, T. Matsumoto, H. Yamamoto, A Case of Spindle Cell Carcinoma of the Oral Cavity: With Special Reference to Cytopathological Features and Review of Literature. Oral Med Patholm, 11, 2006,127

[14] R.J. Zarbo, J.D. Crissman, H. Venkat, M.A. Weiss, Spindle-cell carcinoma of the upper aerodigestive tract mucosa: an immunohistologic and ultrastructural study of 18 biphasic tumors and comparison with seven monophasic spindle-cell tumors. Am J Surg Pathol, 10, 1986, 741-753.

[15] J.E. Lewis, K.D. Olsen, T.J. Sebo, Spindle cell carcinoma of the larynx: review of 26 cases including DNA content and immunohistochemistry, Hum Pathol, 28, 1997, 664-673.

[16] H.R. Choi, E.M. Sturgis, D.I. Rosenthal, M.A. Luna, J.G. Batsakis, A.K. El-Naggar, Sarcomatoid carcinoma of the head and neck: molecular evidence for evolution and progression from conventional squamous cell carcinomas, Am J Surg Pathol, 27, 2003, 12161220 . 
[17] T.A.Steeper, F. Piscioli, J. Rosai, Squamous cell carcinoma with sarcoma-like stroma of the female genital tract: clinicopathological study of four cases. Cancer, 52, 1983, 890-898.

[18] J.S. Lewis, J.H. Ritter, S. El-Mofty, Alternative epithelial markers in sarcomatoid carcinomas of head and neck, lung, and bladderp63, MOC-31 and TTF-1, Mod Pathol, 18, 2005, 1471-1481.

[19] M. Diaz-Guerra, S. Haddow, C. Bauluz, J.L. Jorcano, A. Cano, A. Balmain, M. Quintanilla, Expression of Simple Epithelial Cytokeratins in Mouse Epidermal Keratinocytes Harboring Harvey ras Gene Alterations, Cancer Res, 52, $1992,680-687$.

[20] H. Battifora Spindle cell carcinoma: ultrastructural evidence of squamous origin and collagen production by tumor cells. Cancer, 37, 1976, 2275-2282.

[21] R. Munakata, J. Cheng, T. Nakajima, T. Saku, Spindle cell carcinoma of the gingiva: report of an autopsy case, J Oral Pathol Med, 27, 1998, 180-184.

[22] R.E. Fechner, Pathologic Quiz Case 1, Arch Otolaryngol Head Neck Surg, 116, 1990, 110-112.

[23] A.A. Gal, S.E. Martin, J.A. Kernen, M.J. Patterson, Esophageal carcinoma with prominent spindle cells, Cancer, 60, 1987, 22442250 ..

[24] R.J. Zarbo, J.D. Crissman, H. Venkat, M. A. Weiss, Spindle-cell carcinoma of the upper aerodigestive tract mucosa: An immuno-histologic and ultrastructural study of 18 biphasic tumors and comparison with seven monophasic spindle-cell tumors, Am J Surg Pathol, 10,1986, 741-753.

[25] T. Takata, H. Ito, I. Ogawa, M. Miyauchi, N. Ijuhin, H. Nikai Spindle cell squamous carcinoma of the oral region: An immunehistochemical and ultrastructural study on the histogenesis and differential diagnosis with a clinicopathological analysis of six cases, Virchows Arch A Pathol Anat, 419, 1991, 177-182.

[26] S. Kessler, M.H. Bartley, Spindle cell squamous carcinoma of the tongue in the first decade of life, Oral Surg Oral Med Oral Pathol, 66,1988, 470-474.

[27] G.L. Ellis, R.L. Corio, Spindle cell carcinoma of the oral cavity: A clinicopathologic assesssment of fifty-ninecases, Oral Surg Oral Med Oral Pathol, 50, 1980, 523-534.

[28] A. Mohanta, P.K. Mohanty, G. Parida, Genotoxicity of tobacco and alcohol on human oral mucosal cells, Euro. J. Exp. Bio., 3(2), 2013, 503-514

[29] A. Mohanta, P.K. Mohanty, G. Parida, Pattern of Keratinization in Oral Squamous Cells during Carcinogenesis, IOSR Journal of Dental and Medical Sciences, 13 (7), 2014, 83-91.

[30] R.D. Köseoğlu, A. Sertçelik, Y. Ayva, A rare variant of squamous cell carcinoma of the tongue; spindle cell carcinoma, Journal of Ankara University Faculty of Medicine, 58(1) , 2005, 11-14

[31] H.H. Su, S.T. Chu, Y.Y. Hou, K.P. Cjang, C.J. Chen, Spindle cell carcinoma of the oral cavity and oropharynx: factors affecting outcome., J Chin Med Assoc, 69, 2006, 478-483.

[32] N. Parikh, N. Desai, Spindle cell carcinoma of the oral cavity: A case report of a rare entity and review of literature, Journal of Academy of Advanced Dental Research, 2(2), 2011,31-36.

[33] L.D.R. Thompson, Squamous cell carcinoma variants of the head and neck, Curr Diagn Pathol, 9, 2003, 384-96. 